\title{
COVID-19 and Research in International Law
}

\author{
Fuad Zarbiyev
}

If you can think about something which is attached to something else without thinking about what it is attached to, then you have what is called a legal mind. ${ }^{1}$

Lawyers have a notorious reputation for being boring at parties. The episode of covid-19 confirmed that they are also bad intellectual company. The former may not be remediable - while boredom may well be a suitable object of investigation for cognitive neuroscientists, it is hard to explain why we find some people or experiences boring. The latter is more easily amenable to rational discussion and it is what this short essay will concern itself solely with.

Because it was experienced as an unprecedented crisis on several grounds and/or because it generated a considerable amount of free time for professionals of intellectual labour at least in the Global North, CoviD-19 has triggered reflections about governance and governmentality, the politics of science, modes of crisis management, the place of humans among the living and many other cross-disciplinary themes. ${ }^{2}$ Obviously, a global crisis of such magnitude could not leave international law scholars indifferent - after all, theirs is 'a discipline of crisis', as Hilary Charlesworth put it in a celebrated essay. Most of the scholarship produced by international legal scholars on Covid-19 seems easily vulnerable to Charlesworth's devastating critique given its unproblematic assumption of facts, oversimplification of history and the inflated role assigned to international law. But it is possible to approach that scholarship from a different angle. One of the most remarkable things about international legal scholarship on COVID-19 is that it has largely remained limited to more

1 Thomas Reed Powell as quoted in Pierre Schlag, The Enchantment of Reason, Durham and London, Duke University Press, 1998, p. 121.

2 For an interesting collection, see Collectifs, Tracts de crise: Un virus et des hommes (Gallimard 2020).

(C) FUAD ZARBIYEV, 2022 | DOI:10.1163/9789004472365_020

This is an open access chapter distributed under the terms of the CC BY-NC-ND 4.o licensearbiyev - 9789004472365 
or less imaginative descriptions of relevant legal instruments and possible remedies offered by the latter. Some themes such as the International Health Regulations of the WHO or the power of States to derogate from their obligations under human rights treaties have received extensive attention due to their immediate practical relevance under the circumstances. Others such as the question of whether China could be sued before the International Court of Justice might seem more far-fetched but were squarely within what lawyers are expected to discuss. Common to most of these contributions was the depressing lack of anything that could be dignified with the adjective 'intellectual' if one means by 'intellectual' the quality that furthers one's understanding beyond what should be obvious immediately or in a matter of minutes to any decently trained international legal professional capable of competently reading and interpreting legal materials.

It would be impossible to properly discuss within the limits of this short essay what this state of affairs tells us about research in international law in general, or crisis scholarship in particular. What I want to do instead is to reflect on some conditions that make this reality possible or even unavoidable and conclude with a deliberately provocative proposition.

In a famous passage of Dawn dedicated to the perspectival nature of all knowledge, Nietzsche writes that 'We hang within our web, we spiders, and no matter what we capture in it, we can capture nothing whatsoever other than what allows itself to be captured precisely in our web'. ${ }^{3}$ This point can be reformulated as a general law governing research. In Pierre Schlag's words, this law would state something like this: 'One can only find what the search allows in the sense that the search fails to recognize anything else. ${ }^{4}$ What this means among other things is that what we find as a result of our research is a function of the tools that we use. Just as we have to use appropriate telescopes instead of eyeglasses to see far away galaxies, we cannot be expected to find something that our research - because it is designed the way it is - cannot allow us to find.

If this is so, the question that arises immediately is what is lacking in international law scholars' toolbox: what prevents them from saying something intellectually edifying on CoviD-19, something beyond the issue of what some rules mean or whether a lawsuit could be brought against a culprit? Part of the response can be found in what sociologists would call international law scholars' attentional socialization. What is relevant and what deserves attention in a profession is not determined by some natural laws, but by disciplinary training

3 Friedrich Nietzsche, Dawn: Thoughts on the Presumptions of Morality (Brittain Smith trs, Stanford University Press 2011) 88.

4 Pierre Schlag, The Enchantment of Reason (Duke University Press 1998) 4. 
and professional socialization. In other words, international law scholars do not even attempt to say anything intellectually edifying on CoviD-19, because they have not been trained and socialized in such a way that could make them see something beyond rule description and lawsuits as relevant to their profession.

It is sometimes assumed that this is a perfectly normal situation because law is a vocational trade. Another widespread assumption is that narrowmindedness, resistance to 'the temptation to stray into other fields' is part of the very definition of law. ${ }^{5}$ But these assumptions ignore that law can give rise to numerous professional roles, and that if international law is what a group of professionals do in various professional capacities (academic, judge, arbitrator, litigation counsel, activist, legal advisor to a government or an international organization etc.), it would be misleading to assume that all these professionals pursue the same projects. What is central for the purposes of this essay is to realize that an academic perspective on law cannot legitimately be the same thing as the perspective of a legal professional engaged in legal practice and acting in that capacity.

What do international legal scholars miss when the toolbox they use to study law is 'nothing but the self-replication of legal practice itself'? 6 The most obvious problem with such a toolbox is that it is unlikely to enable international legal scholars to see that at least sometimes law may be part of the problem rather than the proper remedy: the tools of legal practice are hardly suited to diagnose that same legal practice as a problem. Another intellectual limitation of this approach has to do with the fact that mainstream legal scholars enter a scene that is already completely configured by law: if the tools of legal practice are all they have, those scholars will have a hard time re-imagining law because legal discourse is successful in making legally sanctioned social arrangements look natural or unavoidable. It seems as if, for mainstream legal scholars, law only comes into the picture if and when applied by official institutions. That law and its distributional consequences may have something to do with the state of affairs prevailing in the world at any given point in time even outside law's formal application can hardly cross the mind of the legal scholar whose conceptual tools are the ones provided by legal practice.

'[T] he distinction between the subject studying the law and the legal practice that is the object of study' ${ }^{\prime 7}$ or, what ethnomethodologists call the

5 Gerald Fitzmaurice, 'The United Nations and the Rule of Law' (1953) 38 Transactions of the Grotius Society 135, 142.

6 Paul Kahn, The Cultural Study of Law. Reconstructing Legal Scholarship (University of Chicago Press 1999) 27.

7 ibid 7 . 
distinction between topic and resource -is not an option that only some highly theoretically minded academics could find attractive; it is the raison d'être of legal academia in the sense that anyone who does not endorse that distinction has nothing legitimate to do in academia. The possible objection that mainstream international legal academics do something different from legal practitioners misses the mark. When a scholar's objective is to clarify the state of the law, clear up any confusion surrounding it and deliver a verdict on what the international law is on a particular issue, that exercise is no different from what practitioners do simply because it is not performed before an official institution like a court. A scholar may come up with a more nuanced account accompanied with more footnotes, but that would be a difference in degree, not in kind.

There is a social cost that a society pays when an academic does not do the job that they are expected to do and does the job that is expected from members of a different professional occupation. To be fair, there may be a social gain when those professionals and academics join forces to do the same job. But it is hard to believe that such a social gain necessarily justifies the social cost of a reduction in serious academic research worthy of the name. Hence an invitation to international law academics: if for any reason, you don't feel that you can conceive of academic work in any terms other than the terms of legal practice, please leave academia and engage in practice as a full-fledged practitioner. You will then have no impostor syndrome, which you must experience from time to time, and who knows, the academic position you will have made available by leaving academia can be occupied by someone actually willing and able to do the job that the society at large considers - and rightly so - as part of a separate professional occupation. 